\title{
HAS JOMTIEN MADE ANY DIFFERENCE? TRENDS IN DONOR FUNDING FOR EDUCATION AND BASIC EDUCATION SINCE THE LATE 1980s
}

\author{
by Paul Bennell with Dominic Furlong ${ }^{1}$
}

\author{
IDS Working Paper 51
}

\begin{abstract}
Summary
The Education For All Conference, which was co-sponsored by three United Nations agencies (UNESCO, UNICEF and UNDP) and the World Bank, was held in Jomtien, Thailand in March 1990. In the Declaration which emerged from the conference, both developing country governments and donor agencies committed themselves to the goal of ensuring basic education for all children by 2000. This paper assesses the extent to which aid donors have responded to the challenge of Jomtien, in particular the degree to which the funding of basic education has increased since 1990. The two main conclusions of this assessment are: (i) in real terms, total aid for the education sector from bilateral donors was lower in the mid-1990s than before the EFA Conference; and (ii) that, while education aid from some education donors has been reallocated in favour of basic education, actual support for basic education among the main bilateral donors is very uneven and that, taken as a whole, the additional external resources that have been and are likely to be forthcoming will be insufficient to meet the basic objective of 'education for all' by the year 2000 .
\end{abstract}

1 Fellow and formerly Research Assistant, respectively, at the Institute of Development Studies. We are very grateful to Julia Benn and her colleagues at the Development Cooperation Secretariat, OECD and the following education advisers at both bilateral and multilateral donor agencies: Myriam Martinez Elcoro (AECI), Sam MacGregor and Bartolome Amat (EC), Willy Clarke-Okah (CIDA), Hanke Koopman (DGIS), Jean-Claude Balmes (Ministere de la Cooperation, France), Sissel Volan (NORAD), Malcolm Seath (ODA), Lars Bruun Rasmussen (Royal Danish Ministry of Foreign Affairs), Christine McNab (SIDA), Marie Byll (Swiss Aid), Bradford Strickland (USAID), Marlaine Lockheed (World Bank). Information (statistical data and/or publications) was also furnished by AUSAID, BMZ (Germany), Ministry of Foreign Affairs, Finland, and Ministry of Foreign Affairs, Italy, Ministry of Foreign Affairs, New Zealand and also Lene Buchert and Kenneth King. Christopher Colclough and Adrian Wood made very useful comments on a first draft of this paper. The usual disclaimers apply. 


\section{INTRODUCTION}

The need for comprehensive and sustained human resource development is central to the new poverty alleviation development agenda of the 1990s. In particular, universal access to better quality basic education has been singled out as being of fundamental importance in any concerted attempt to improve the standard of living of the poor, and especially poor women and their children, in developing countries. Another body of research has also clearly demonstrated that the mass provision of good quality primary, but also increasingly secondary, education is essential if countries are to compete successfully in a rapidly globalising world economy and, more generally, attain high and sustainable rates of economic growth (see Wood, 1994).

Given the critical dual role of education in contributing to both equity and growth objectives, it is comes as no surprise that the two most important recommendations in the World Bank's recently published education sector review are that "greater attention" should be given to education as a whole by both governments and donor organisations and that, within the publicly funded education sector itself, top priority should be given to primary education in those countries where net enrolment ratios are below 100 percent and/or where the overall quality of primary education remains poor (see World Bank, 1995a). In a similar vein, the World Declaration on Education For All (EFA) that emerged from the Jomtien Conference in March 1990 stated that there is now "a world-wide consensus on an expanded vision of basic education that surpasses present resource levels, institutional structures, curricula and conventional delivery systems" (UNESCO et al, 1990:2). While emphasising that it is the responsibility of national governments to formulate and implement their own EFA policy frameworks, it was clearly recognised at Jomtien that "increased international funding is needed to help" (ibid:17). More specifically, Haddad estimated in 1990 that the donor community would need to provide an additional US\$1.0-1.3 billion of educational assistance each year if the EFA target of primary schooling for all was to be met by the target date of 2000 (see Haddad, 1990). Colclough and Lewin also produced another set of estimates of additional donor assistance needed to meet the EFA targets. They concluded that, even with significant educational and financing reforms together with increased domestic spending on education, US $\$ 2.5$ billion of targeted donor assistance would still be needed on an annual basis (see Colclough with Lewin, 1993).

The purpose of this paper is to present and discuss the results of recently undertaken research that assesses the extent to which this "expanded vision" has resulted in increased resource commitments by bilateral and multilateral aid donors to the education and training sectors in developing countries, and in particular for basic education. The Working Document prepared by the Secretariat of the International Consultative Forum on Education For All for the 1996 MidDecade Review of EFA targets and other goals confidently states that "aggregate donor commitments and disbursements for basic education have risen in absolute and relative terms" (EFA, 1996:16). However, the principal finding of our research is that, in real terms, total aid for the education sector from bilateral donors was in fact lower in the mid 1990s than before Jomtien. Furthermore, while education aid from some donor countries has been reallocated in favour of basic education, support for basic education among the main bilateral donors is very uneven and that, taken as a whole, the additional external resources that have been and are likely 
to be forthcoming will be insufficient to meet the basic EFA objective of 'education for all' that meets basic learning needs by the year 2000 .

The discussion is structured as follows. Section 2 briefly describes the main sources of data that have been used for this analysis. Section 3 then examines donor resource commitments to the education sector as a whole, and Section 4 analyses trends in donor expenditure commitments for basic education since Jomtien.

\section{DEFINITIONS AND DATA SOURCES}

Any analysis of support for "basic education" by aid donors is complicated by the fact that there is no common definition of what is and is not basic education. There are donors, most notably the World Bank, who adopt a narrower operational definition of basic education which is largely confined to formal primary schooling. ${ }^{1}$ Most other donors however, prefer the wider concept of basic education that emerged from Jomtien which covers "all the knowledge and skills which people need if they are to lead a decent life" (DGIS, 1994:13). These "basic learning needs" include therefore early childhood education, primary schooling, and non-formal literacy, numeracy and other programmes for youth and adults including vocational training that helps to provide the basic life skills. Given the Bank's current aversion to funding adult education and vocational education and training, it is clear that the definition of basic education is itself a source of debate and dispute within the donor community.

The Development Assistance Committee (DAC) of the OECD has formal responsibility for collecting and compiling statistics on aid commitments and disbursements of all 21 member countries of the OECD. Its main annual publication, Development Assistance, presents information on the percentage of total bilateral aid commitments allocated to education from which it is possible to calculate the total value of commitments for education. Since 1994, percentage allocations for basic education have also been presented, but these cover only a minority of mainly smaller donors.

Unfortunately, the DAC's own data base on individual aid projects (the 'Creditor Reporting System') is of relatively limited use in analysing trends in education aid. The CRS records key information on individual projects, most notably the donor country and organisation, the recipient country, year of initial disbursement, type of activity supported, and total size of the financial assistance (in US dollars). Education projects are classified and coded into 13 subcategories which can be re-grouped to correspond with basic (i.e. primary, non-formal and preschool), secondary, and higher education, vocational training, and 'other'. However, the two main limitations of the CRS with respect to the education sector are that: (i) only 25-30 percent of all education aid is accounted for in any one year. For major aid donors, most notably Germany, France and Japan, only a very small fraction (typically less than 5 percent) of total education aid is recorded by the CRS. This is mainly because technical assistance, which for most donors comprises the bulk of education aid, is not generally included. Hence, only for those donors where all or most of their education aid is included is it possible to use the CRS to analyse trends 
in the composition of education aid; (ii) the types of education aid included in the 'other' education grouping are education projects that are intended to support education systems as a whole (e.g. planning and management) or activities such as "building and equipment' that do not specify which particular types of education are being assisted. Typically, these activities account for a large proportion (25-40 percent) of total education aid so, without additional research, it is unclear precisely how much aid is being devoted to the four main types of education and training.

The EFA Forum Secretariat based at UNESCO undertook its own "review of the performance of bilateral and multilateral agencies in basic education". However, "relevant statistical data" were only available from 9 of the 21 DAC bilateral donors and, even among these donors, there are no uniform time series data on absolute and relative expenditures for basic education. Consequently, while this review contains some useful information on individual donors, it is unable to provide a satisfactory overview of trends in donor funding for basic education since 1990. For this reason, we decided to re-survey all the bilateral donors in order to obtain basic statistical data on education aid expenditures since 1990 (disaggregated, wherever possible, into the main CRS education sub-categories) as well as other relevant policy documentation on the education sector. All the large bilateral donors provided this information. Other secondary sources were also consulted, most notably donor annual reports and a very useful survey of European Union Member States' education assistance to developing countries conducted by the European Commission in 1995 (see European Commission, 1995). Drawing on these various data sources, it has been possible to undertake a reasonably accurate and comprehensive analysis of donor funding for education and basic education since Jomtien.

\section{OVERALL DONOR COMMITMENTS TO EDUCATION}

\section{(a) Relative Resource Commitments}

The most obvious indicator of donor commitment to the education sector as a whole is the proportion of each donor's total aid budget allocated to education activities. DAC data are only available for commitments so it is not possible to say exactly what disbursement expenditures have been. Among the large majority of donors, commitments have regularly exceeded expenditures by approximately 10-15 percent during the last ten year. It is also the case that not all education and training activities are always included in the 'education' category.

Before discussing changes in the share of education aid since Jomtien, it is worthwhile to review briefly trends in donor funding to the education sector in the period leading up to the Conference in early 1990. While total development assistance had grown fairly rapidly since the mid 1980s, education aid as a percentage of total commitments fell or stagnated in the large majority of donor countries between 1985-86 and 1989-90 with, furthermore, most donors continuing to give fairly minimal support to basic education (see Table 1). During the early-mid 1980s, only about five percent of total education aid was devoted to basic education activities (see Lockheed and Verspoor, 1990). The World Bank, on the other hand, started to increase significantly its lending to the education sector and, in particular, primary education from the mid-1980s. The Bank's own 
education sector specialists were eager to use the Bank's increasingly influential financial and intellectual position in the education sector to encourage the bilateral donors to pay "more attention" to education and especially primary education. ${ }^{3}$ Jomtien was, therefore, a critical moment in this strategy to raise the profile of education aid and re-orientate donor priorities within the education sector. ${ }^{4}$

Table 1: $\quad$ Percentage of bilateral aid committed to education 1985-1994.

\begin{tabular}{|c|c|c|c|c|c|c|c|}
\hline Donor & $1985-86$ & $1987-88$ & $1989-90$ & $1991-92$ & 1993-94 & 1995 & $\begin{array}{c}\text { Change } \\
1989 / 90-1993 / 94\end{array}$ \\
\hline Australia & 22.3 & 15.8 & 31.5 & 21.9 & 18.3 & 22.9 & -13.2 \\
\hline Austria & 38.4 & 22.1 & 16.4 & 15.3 & 15.0 & 18.0 & -1.4 \\
\hline Belgium & 28.6 & 23.7 & 21.1 & 15.0 & 13.2 & 13.4 & -7.9 \\
\hline Canada & 8.1 & 6.7 & 12.3 & 6.7 & 6.2 & 8.4 & -6.1 \\
\hline Denmark & 2.9 & 3.4 & 1.4 & 8.1 & 5.3 & 5.2 & 3.9 \\
\hline Finland & 7.7 & 3.8 & 3.1 & 3.5 & 3.8 & 6.6 & 0.7 \\
\hline France & 26.5 & 22.9 & 26.4 & 23.7 & 24.5 & .. & -1.9 \\
\hline Germany & 19.9 & 19.0 & 15.2 & 13.0 & 15.3 & .. & 0.1 \\
\hline Ireland & 20.3 & 18.7 & 21.6 & 24.6 & 27.9 & .. & 6.3 \\
\hline Italy & 4.3 & 5.3 & 6.0 & 5.2 & 4.0 & 5.7 & -2.0 \\
\hline Japan & 8.1 & 6.2 & 6.4 & 6.3 & 7.2 & 8.8 & 0.8 \\
\hline Netherlands & 10.8 & 5.0 & 10.3 & 9.2 & 4.6 & 5.5 & -5.7 \\
\hline New Zealand & 9.8 & 52.6 & 1.6 & 35.8 & 34.1 & .. & 32.5 \\
\hline Norway & 8.3 & 10.1 & 6.5 & 4.8 & 2.4 & 3.0 & -4.1 \\
\hline Sweden & 7.3 & 6.6 & 4.6 & 6.7 & 6.8 & 8.4 & 2.2 \\
\hline Switzerland & 7.2 & 7.5 & 9.8 & 7.7 & 6.0 & 3.0 & -3.8 \\
\hline United Kingdom & 12.8 & 10.3 & 12.0 & 12.6 & 11.4 & 10.1 & -0.6 \\
\hline United States & 3.8 & 4.7 & 4.0 & 2.8 & 4.5 & 4.1 & 0.5 \\
\hline DAC Total & 10.9 & 11.0 & 10.2 & 8.5 & 10.1 & 8.1 & -0.1 \\
\hline
\end{tabular}

Note: Bi-annual percentage averages are unweighted.

$$
. .=\text { not available }
$$

Source: $\quad$ Calculated from data in OECD, Development Assistance Committee, Development Cooperation, various years, and unpublished data for 1994 and 1995. 
Table 2: Bilateral donor commitments to education (US\$ million), 1986-1994

$\%$ Change

$1989 / 90$ - 1993/94

\begin{tabular}{|c|c|c|c|c|c|c|c|c|c|c|c|}
\hline Donor & 1986 & 1987 & 1988 & 1989 & 1990 & 1991 & 1992 & 1993 & 1994 & $\begin{array}{c}\text { Current } \\
\text { prices } 1 \\
\end{array}$ & $\begin{array}{r}\text { Constant } \\
1993 \text { prices }^{\mathrm{a}} \\
\end{array}$ \\
\hline Australia & 110 & 105 & 147 & 128 & 181 & 146 & 107 & 177 & 136 & 13.4 & -2.1 \\
\hline Austria & 33 & 42 & 44 & 46 & 72 & 111 & 111 & 99 & 97 & 113.3 & 87.6 \\
\hline Belgium & 101 & 99 & 101 & 89 & 97 & 74 & 83 & 69 & 54 & -35.3 & -44.3 \\
\hline Canada & 59 & 180 & 128 & 249 & 202 & 125 & 120 & 61 & 130 & -49.6 & -56.1 \\
\hline Denmark & 13 & 12 & 22 & 7 & 8 & 62 & 54 & 73 & 23 & 231.0 & 181. \\
\hline Finland & 18 & 0 & 15 & 28 & 10 & 37 & 10 & 9 & 7 & -62.8 & -67. \\
\hline France & 939 & 1333 & 1357 & 1766 & 2301 & 1378 & 1506 & 1513 & 1633 & 0.8 & -12 . \\
\hline Germany & 678 & 820 & 785 & 753 & 831 & 699 & 864 & 795 & 1073 & 21.5 & \\
\hline Ireland & 5 & 6 & 4 & 4 & 0 & 6 & 8 & 0 & 10 & 25.0 & 53 \\
\hline Italy & 92 & 124 & 159 & 116 & 145 & 196 & 98 & 96 & 37 & -51.6 & -58 \\
\hline Japan & 363 & 453 & 480 & 459 & 704 & 826 & 729 & 882 & 1215 & 123.3 & 91 \\
\hline Netherlands & 129 & 86 & 116 & 138 & 275 & 207 & 121 & 67 & 144 & -61.6 & -28 \\
\hline New Zealand & 0 & 13 & 49 & 0 & 1 & 39 & 22 & 24 & 29 & 8.2 & -11 \\
\hline Norway & 41 & 43 & 6 & 35 & 29 & 37 & 27 & 14 & 18 & -22.0 & -30 \\
\hline Portugal & 0 & 0 & 0 & 0 & 0 & 0 & 37 & 0 & 45 & 0.0 & \\
\hline Spain & 0 & 0 & 0 & 10 & 53 & 64 & 55 & 51 & 48 & 0.0 & \\
\hline Sweden & 57 & 60 & 65 & 46 & 74 & 135 & 74 & 92 & 91 & 64.9 & 40 \\
\hline Switzerland & 10 & 37 & 39 & 53 & 57 & 53 & 51 & 39 & 39 & -15.2 & -26 \\
\hline United Kingdom & 126 & 149 & 172 & 220 & 228 & 299 & 268 & 202 & 179 & -2.8 & -15 \\
\hline United States & 320 & 364 & 402 & 455 & 452 & 452 & 430 & 405 & 372 & -9.3 & -21 \\
\hline Totals: & 3094 & 3926 & 4091 & 4602 & 5720 & 4946 & 4775 & 4668 & 5380 & 14.3 & \\
\hline
\end{tabular}

Note: a OECD/DAC deflator used.

Source: Calculated from data in OECD, Development Assistance Committee, Development Cooperation, various years, and unpublished data for 1994 and 1995. 
What then has happened since Jomtien? As noted earlier, the overriding importance of human resource development in alleviating poverty and for national economic development in general has been repeatedly emphasised by all the major aid donors since the late 1980s. However, so far as the education sector is concerned, by the mid-1990s these policy pronouncements had not resulted in any significant increase in the education sector's overall share of total bilateral assistance. Table 1 shows that the overall percentage of the total bilateral aid budget committed to education actually fell from 10.2 percent in 1989-90 to 8.5 percent in 1991-92, and increased only slightly to 10.1 percent in 1993-94. The DAC estimates for 1995 are not yet complete but what are available strongly suggest that the overall percentage allocated to education was well below 10 percent.

These aggregate figures also mask very large variations among individual bilateral donors in the changing shares of education aid. During 1989-1994, this share declined very significantly in Australia (-12.7 percentage points), Belgium (-13.5), Canada (-4.7), Switzerland (-6.3), and Norway (-5.8), with smaller declines being recorded in France (-3.4), Italy (-2.7), the Netherlands (-1.6), the United Kingdom (-1.1), and the United States (-1.1). Education's share increased only in Austria (1.6 percentage points, although if 1990 is taken as the starting year, the share declined from 21.5 percent to 12.8 percent in 1994), Denmark (1.6), Germany (0.9), Ireland (6.3), Japan (2.7), and Sweden (3.0). The very small proportion of aid devoted to education is particularly noticeable in Denmark, Finland, Italy, Norway, and the United States. ${ }^{1}$

In marked contrast, the overall share of World Bank (including IDA) lending for education projects increased from 4.5 percent in 1989 to 10.4 percent in 1994, but fell to 7.9 percent in 1996 (see Table 3). It is interesting to note that while education advisors and specialists at the World Bank believe that they are playing an increasingly important "leadership role" among the donor education community (see World Bank, Annual Report 1995:21), the Bank's increased policy commitment to human resource development and in particular education has only brought its relative resource allocation to education up to the aggregate share that prevailed among the bilateral donors throughout this period. In part, this is because the Bank must obviously respond to the lending needs of its client governments over which it has only varying degrees of control. Specifically, there are two types of Bank lending, namely standard IBRD loans to client countries at commercial rates of interest and soft loans on highly concessional terms from the International Development Association (IDA) to low income developing countries. Countries that borrow on commercial terms from the Bank have a much higher degree of control over the projects that are eventually funded, compared with those that receive IDA loans. Table 3 shows that the education sector's share of IBRD (i.e. commercial) lending has been approximately half of the percentage share for IDA lending. Thus, in the case of IDA resources, where the Bank has been able to largely control what projects it is prepared to fund and which therefore conform more to lending policy pronouncements emanating from Washington, the Bank is clearly taking the lead in giving "greater attention" to education. The problem of translating this objective into practice has however been much greater with respect to IBRD loans proper (which comprise the bulk of total Bank lending) ${ }^{5}$ where it would appear that client governments are considerably less enthusiastic about borrowing for projects in the education sector at commercial rates of interest. 
The multilateral Regional Development Banks have also responded to the lead given by the World Bank. In fact, the increase in the share of education sector lending among these organisations has been even more impressive than at the World Bank itself - rising from 4.3 percent in 1985-86 to 16.6 percent in 1993-94. Unfortunately, comparable statistics for the $\mathrm{UN}$ agencies and the $\mathrm{EC}$ are not available.

Table 3: World Bank commitments to education, 1988 - 1996 (US\$ million).

\begin{tabular}{|c|c|c|c|c|c|c|c|}
\hline \multirow[b]{2}{*}{ Year } & \multicolumn{3}{|c|}{ Education } & \multirow[b]{2}{*}{$\begin{array}{c}\text { Total World } \\
\text { Bank Lendinga } \\
\end{array}$} & \multicolumn{3}{|c|}{$\begin{array}{l}\text { Education as \% of } \\
\text { total lending }\end{array}$} \\
\hline & IBRD & IDA & Total & & IBRD & IDA & Total \\
\hline 1988 & 655 & 209 & 864 & 19221 & 4.4 & 6.6 & 4.5 \\
\hline 1989 & 515 & 449 & 964 & 21367 & 3.1 & 9.1 & 4.5 \\
\hline 1990 & 530 & 957 & 1487 & 20702 & 3.5 & 17.3 & 7.2 \\
\hline 1991 & 1516 & 736 & 2252 & 22686 & 9.2 & 11.7 & 9.9 \\
\hline 1992 & 1300 & 584 & 1884 & 21706 & 8.6 & 8.6 & 8.7 \\
\hline 1993 & 968 & 1038 & 2006 & 23696 & 5.7 & 15.4 & 8.5 \\
\hline 1994 & 1500 & 658 & 2158 & 20836 & 10.5 & 10.0 & 10.4 \\
\hline 1995 & 1280 & 816 & 2097 & 22522 & 7.6 & 14.4 & 9.3 \\
\hline 1996 & 921 & 785 & 1706 & 21520 & 6.2 & 11.4 & 7.9 \\
\hline 1990-96 & 8015 & 5574 & 13590 & 153668 & 7.3 & 12.7 & 8.8 \\
\hline
\end{tabular}

Note: $\quad$ a for all activities

Source: $\quad$ World Bank Annual Reports, various years.

\section{(b) Absolute Resource Commitments}

Absolute expenditure commitments for education by the DAC donors for the period 1986 to 1994 are shown in Table 2. In constant price terms, total bilateral donor commitments to education declined by 1.6 percent from 1989-90 to 1993-94. Approximately 90 percent of this decline can be attributed to the fall in total development assistance for bilateral programmes during this period, with the remainder being accounted for by the slightly lower share of education in total commitments. 
Looking at individual donors, it can be observed in Table 2 that the real value of commitments to the education sector declined by over a half in Canada, Finland and Italy. In Belgium, the Netherlands, Norway, and Switzerland, the fall was between 25 and 49 percent. Only in Austria, Denmark, Germany, Ireland, Japan and Sweden did the real value of donor commitments to education actually increase. Total bilateral commitments did increase quite appreciably (by 13.2 percent in current prices) in 1994, but, since the DAC have not yet released more recent expenditure data by purpose, it is not clear whether further increases occurred in 1995 and 1996.

Among the bilateral donors, France accounted for 40.6 percent of all education aid in 1990 although by 1994 this had fallen to 30.4 percent. $^{6}$ During this same five year period, Japan's share almost doubled - from 12.4 percent in 1990 to 22.5 percent in 1994 . Four countries (France, Germany, Japan and the United States) accounted for almost 80 percent of all bilateral education aid. With the rapid growth in the World Bank's commitments to education, the Bank's share of total donor assistance to the education sector rose appreciably- from - 17.4 percent in 1988 to 28.6 percent in 1994.

The DAC classifies all aid commitments and disbursements into four functional categories, namely investment projects, sector aid, technical cooperation, and other. Within the education sector, technical cooperation has consistently accounted for 70-75 percent of all donor support since the mid 1980s. A large slice of technical cooperation is usually spent in the donor country itself on education and training courses for nationals from developing countries. Data are not available for a number of important donors (including the United States and Japan), but, typically, 60-80 percent of all education aid commitments are spent in recipient countries. No particular trend is apparent in the division of education expenditures between donor and recipient countries.

Turning to the multilateral donors, Table 3 shows that World Bank lending for education increased from an average of US\$914 million in 1988-89 to US\$1902 million in 1995-96, a nominal increase of 108 percent. However, it can be observed in Table 4 that the level of Bank lending for education in Sub-Saharan Africa declined markedly - from around US $\$ 400$ million per year in 1992 and 1993 to one-third of this level by 1996. This is barely five percent of total Bank lending to SSA and less than 10 percent of total Bank lending for education (see Table 4). The reasons for this fall in education lending for SSA are not altogether clear. All Bank projects in SSA are IDA funded, so how these largely Bank controlled resources are allocated among different sectors is, to a large extent, a reflection of the relative priorities attached to these activities by the Bank. It is interesting to note therefore that, at the same time that education lending commitments have declined, funding for projects that are concerned with public sector reform and, more generally, private sector development has mushroomed in recent years. In 1996 alone, lending for public sector reform projects in SSA increased over five times, from US\$ 117 million in 1995 to US\$ 654 million. Thus, while the Bank states publicly that "more attention" should be given to education, in the case of SSA where the education sector in most countries is in desperate need of support, it would appear that even more attention is being accorded to the need to restructure the public and private sectors. 
Table 4 : World Bank lending to the education sector by main geographical region 1986 - 96 (US\$ million).

\begin{tabular}{|c|c|c|c|c|c|c|c|c|c|c|c|c|}
\hline Year & $\begin{array}{l}\text { Sub-Saharan } \\
\text { Africa }\end{array}$ & $\% \mathrm{a}$ & $\begin{array}{c}\text { Middle East } \\
\text { and Asia }\end{array}$ & $\% a$ & $\begin{array}{l}\text { East Asia } \\
\& \text { Pacific }\end{array}$ & $\% a$ & $\begin{array}{l}\text { South } \\
\text { Asia }\end{array}$ & $\% \mathrm{a}$ & $\begin{array}{c}\text { Europe \& } \\
\text { Central Asia }\end{array}$ & $\% \mathrm{a}$ & $\begin{array}{l}\text { Latin America } \\
\& \text { Caribbean }\end{array}$ & $\% a$ \\
\hline $1986-90$ & 167 & 5.6 & 119 & 9.2 & 285 & 7.5 & 222 & 5.6 & 59 & 3.6 & 65 & 1.2 \\
\hline 1989 & 88 & 2.2 & 251 & 17.0 & 170 & 4.1 & 314 & 6.7 & - & - & 140 & 2.4 \\
\hline 1990 & 351 & 11.2 & 31 & 2.2 & 434 & 11.6 & 581 & 16.6 & 90 & 4.1 & - & - \\
\hline 1991 & 266 & 7.8 & 241 & 11.9 & 592 & 13.0 & 307 & 8.5 & 250 & 6.5 & 595 & 11.4 \\
\hline 1992 & 403 & 10.1 & 75 & 5.0 & 474 & 7.7 & 146 & 4.9 & - & - & 597 & 10.5 \\
\hline 1993 & 417 & 14.8 & 115 & 6.1 & 479 & 8.6 & 339 & 9.9 & - & - & 589 & 9.5 \\
\hline 1994 & 326 & 11.6 & 33 & 2.9 & 437 & 7.2 & 220 & 9.3 & 60 & 1.6 & 1083 & 22.8 \\
\hline 1995 & 201 & 8.8 & 158 & 16.1 & 527 & 9.3 & 424 & 14.1 & 40 & 0.9 & 747 & 12.3 \\
\hline 1996 & 132 & 4.8 & 138 & 8.7 & 438 & 8.1 & 500 & 17.0 & 5 & 0.1 & 493 & 11.1 \\
\hline
\end{tabular}

Note: a \% of total World bank lending in each region. 
With increasingly limited IDA resources, this would explain why lending to the education sector has been contracting so rapidly in recent years.

In South Asia, on the other hand, funding for new education projects in 1995 and 1996 averaged US\$ 462 million - 15.5 percent of total Bank funding in the region. Since 1990, by far the highest levels of Bank funding for the education sector have been in Latin America and the Caribbean (LAC), and have been mainly IBRD projects. With the exception of 1994, lending to the education sector accounted for 10-12 percent of total Bank lending in LAC between 1990 and 1996, but the region's share of total Bank lending to the education sector increased from 7.1 percent in 1986-90 to 32.6 percent in 1995-96 (see Table 5). Both in absolute and relative terms, lending to the education sector in East Asia and the Pacific has remained largely unchanged during the 1990s.

Table 5 : Regional shares of World Bank lending to the education sector 1986 - 1996 $(\%)$

\begin{tabular}{lrrrc}
\hline Region & $1986-90$ & $1991-92$ & $1995-96$ & $\begin{array}{c}\text { Change } \\
91 / 92-95 / 96\end{array}$ \\
\hline Sub-Saharan Africa & 18.2 & 16.9 & 8.7 & -8.2 \\
Middle East \& North Africa & 12.9 & 8.0 & 7.8 & -0.2 \\
East Asia \& Pacific & 31.1 & 36.2 & 25.3 & -10.9 \\
South Asia & 24.2 & 11.5 & 24.3 & 12.8 \\
Latin America \& Caribbean & 7.1 & 30.2 & 32.6 & 2.4 \\
Europe \& Central Asia & 6.4 & 6.3 & 1.2 & -5.1 \\
& & & & 100.0 \\
\hline Total & 100.0 & 100.0 & & - \\
\hline
\end{tabular}

\section{DONOR SUPPORT FOR BASIC EDUCATION}

\section{(a) The World Bank}

For over 20 years, but in particular since the early 1980s, education economists and other education specialists at the Bank have very effectively campaigned for increased government and donor funding of primary education. Certainly, the Bank has demonstrated a growing commitment to support primary education. Table 6 shows that since Jomtien in 1990, the Bank has lent a total of US\$ 6.2 billion for basic education projects which amounts to slightly over 50 percent of all lending to the education sector for the period 1991-96. The share of basic education rose particularly dramatically from approximately one third of total education lending during 1989-90 to over 60 percent during 1993-94, but fell back appreciably in 1995 and 1996 to 44 percent.

These aggregate figures mask very sizeable regional variations in the share of basic education in total education lending by the World Bank. While in South Asia this share was over 80 
percent for the period 1991-96, it was barely one half in Sub-Saharan Africa ${ }^{7}$ where primary schooling enrolment ratios are not only much lower but declined significantly in most countries, at least until the early 1990s. In East Asia and the Pacific, basic education projects comprised only a third of all education sector lending.

In analysing these changes in World Bank funding for basic education, a clear distinction must again be made between IBRD and IDA funded education projects. To reiterate, client governments have greater control over the kinds of activities they want funded by the World Bank when they are borrowing at commercial rates of interest while the Bank has much greater say about the projects that it is prepared to support using IDA concessional finance. Given the priority that the Bank attaches to primary education, as Figure 1 shows, the proportion of IDA education projects that focus on primary education has been higher than among IBRD education loans although this has become less pronounced in recent years, especially as more LAC countries have borrowed from the Bank for basic education projects. But, in general, it would appear that, given the choice, governments in middle and high income developing countries (in particular in East Asia and the Pacific and Eastern Europe and Central Asia) have been less interested in borrowing from the World Bank for primary and basic education. ${ }^{8}$ With respect to IDA funds, however, the Bank has been able to ensure that at least half of all education projects funded from this source have been in the areas of primary and basic education.

It can also be observed in Table 6 that Sub-Saharan Africa, the region in the world with the least developed human resources and with the lowest primary and secondary school enrolment ratios, received only 13.3 percent of all new World Bank lending for basic education during 1991-96, while South Asia and Latin America and the Caribbean ended up with 24.8 percent and 40.7 percent respectively. The relatively much higher share for LAC reflects the ability of many of the countries in the region to borrow commercially from the Bank. In SSA and South Asia, on the other hand, most education projects are IDA-funded. One of the main consequences of Jomtien and EFA is that governments in South Asia have sought more support from the Bank for basic education. Given that total IDA funding for education has increased only slightly since 1990, this has meant that the competition for these resources has increased significantly. Consequently, whereas the SSA region got slightly over 50 percent of all IDA resources devoted to education projects in 1991-92, by 1995-96 this share had fallen dramatically to 20.8 percent. Given that the population of South Asia is more than double that of SSA, the level of IDA education funding per capita is now roughly the same for both regions.

In absolute terms, Bank funding for basic education doubled - from US\$437 in 1989-90 to US\$916 million in 1995-96. In SSA, funding for basic education also doubled between 198990 and 1993-94, but then declined significantly, so that by 1995-96 annual Bank lending for basic education was only US\$25 million higher than in 1989-90. With at least one-third of the world's out-of-school children in Africa, coupled with mounting concerns about the deteriorating quality of primary schooling in most African countries, the funding (as opposed to the rhetorical) response of the World Bank since Jomtien to this enormous educational challenge in SSA has been surprisingly muted. The limited additional IDA resources that have been made available will make little impact on the levels of access to and quality of basic education in the continent as a whole. 
Table 6 : World Bank lending for basic education by region, 1989 - 1996 (US\$ million and percentage of total education lending in each region)

\begin{tabular}{|c|c|c|c|c|c|c|c|c|c|c|}
\hline \multirow[t]{2}{*}{ Year } & \multicolumn{2}{|c|}{ Sub-Saharan Africa } & \multicolumn{2}{|c|}{ East Asia \& Pacific } & \multicolumn{2}{|c|}{ South Asia } & \multicolumn{2}{|c|}{$\begin{array}{c}\text { Latin America \& } \\
\text { Caribbean }\end{array}$} & \multicolumn{2}{|c|}{ Global } \\
\hline & $\$ \mathrm{~m}$. & $\%$ & $\$ \mathrm{~m}$ & $\%$ & $\$ \mathrm{~m}$. & $\%$ & $\$ \mathrm{~m}$. & $\%$ & $\$ \mathrm{~m}$. & $\%$ \\
\hline $1989-90$ & 80 & 36.1 & 33 & 10.9 & 172 & 37.9 & 65 & 92.9 & 437 & 35.6 \\
\hline $1991-92$ & 142 & 44.3 & 197 & 40.7 & 73 & 32.1 & 410 & 59.4 & 895 & 43.7 \\
\hline $1993-94$ & 164 & 44.3 & 115 & 27.8 & 236 & 84.3 & 684 & 81.4 & 1267 & 60.9 \\
\hline $1995-96$ & 105 & 63.3 & 167 & 34.5 & 455 & 98.5 & 159 & 25.6 & 916 & 44.0 \\
\hline Total 1991 - 96 & 822 & 48.0 & 958 & 34.7 & 1528 & 79.0 & 2506 & 58.3 & 6156 & 50.9 \\
\hline$\%$ total of BE & - & 13.3 & - & 15.6 & - & 24.8 & - & 40.7 & 100.0 & 100.0 \\
\hline
\end{tabular}

Note: Average annual amount during each two year period. 
Figure 1: Percentage of IDA and IBRD education loans devoted to primary/basic education, 1988-1994

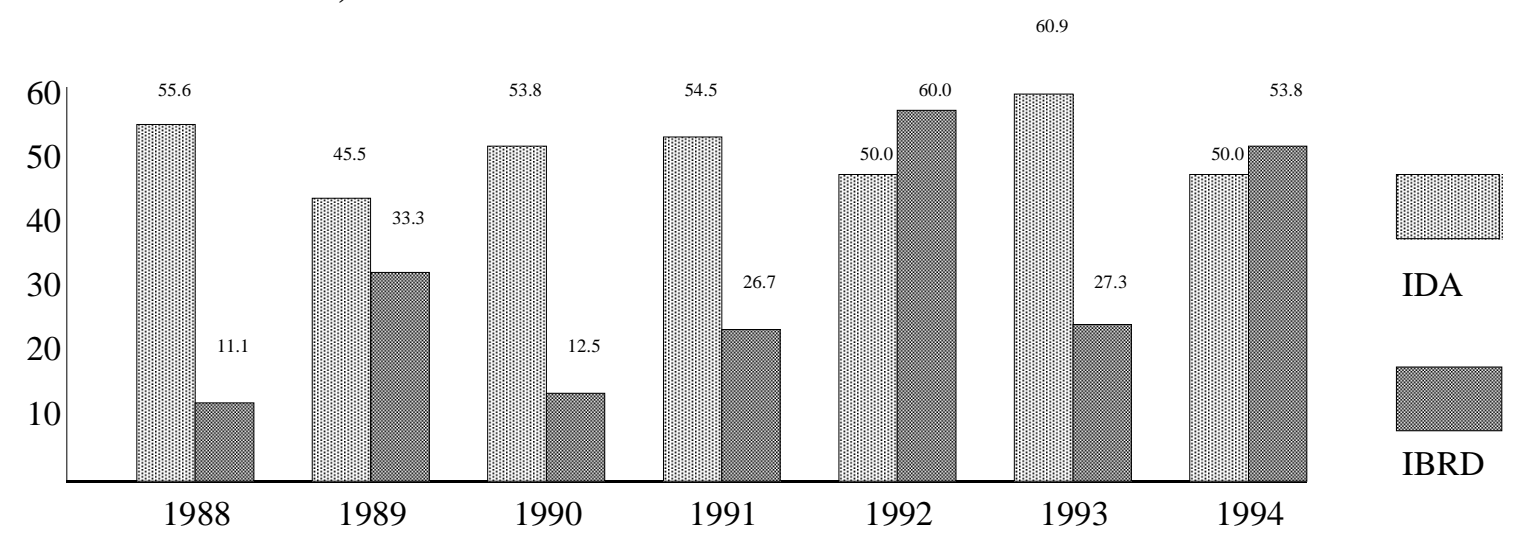

Three reasons for this poor response to Jomtien in SSA by the World Bank have already been identified, namely limited increases in overall IDA funding for the education sector, increased competition from other low income countries, particularly in South Asia, for use of these resources, and within SSA itself increased competition from other sectoral activities (especially public sector reform) which are being accorded very high priority by the Bank as part of the economic reform process. Another likely reason is the considerable additional problems in designing and implementing primary and basic education projects in SSA. As Birger Frederiksen pointed out in 1990 when discussing "the challenge for donors of increasing aid to primary education", the neglect by most donors of primary education in the past can be "explained by their preference for supporting investment projects that are capital and foreign exchange intensive, limited in scope and geographical dispersion so as to facilitate supervision, and fairly heavily dependent on donors' expertise in terms of technical assistance and training. Support for primary education on the other hand would need to be dispersed throughout the country, offers little visibility, and is less dependent on foreign exchange, technical assistance and training abroad" (Fredriksen, 1990:29). His basic contention is therefore that the type of assistance needed to attain significant increases in student achievements at the primary schooling level, "will differ from that typically provided during the last two decades" (ibid:2).

At precisely the same time as the World Bank has been promoting primary education, the Bank has also been making concerted attempts to improve the quality of its lending. Ensuring that client governments take "ownership" of projects is central to this improvement strategy. However, this tends to prolong project preparation, as more responsibility is given to borrowing countries. In the SSA context, where local planning and research capacities in the education sector are still weak, serious delays in project formulation are commonplace. Another major complicating factor is that policy-based lending has become a central feature of Bank and increasingly other bilateral donor support for the education sector in SSA and other low income developing countries. Projects are therefore no longer of the stand-alone variety but are seen as part and parcel of a sector-wide programme of educational reform. While on the one hand, the Bank (especially since the arrival of its new President, James Wolfensohn in 1994) wants to decentralise and give countries greater ownership and control over the resources that are lent by the World Bank, on the other hand, the extension of policybased lending into the education sector signifies a more concerted approach by the Bank and 
the donor community to shape, or at least strongly influence, national educational policy as a whole. Closely linked to this is a greater reliance on policy performance requirements and other types of donor conditionalities.

\section{(b) The UN Agencies and the Regional Development Banks}

As co-sponsors of the Jomtien Conference with the World Bank, UNESCO, UNICEF, and UNDP were already strongly committed to supporting basic education by the late 1980s. Figures for UNDP are unavailable, ${ }^{9}$ but UNICEF already devoted all of its education budget to basic education projects and has continued to do so since then. Slightly more than onethird of UNESCO's education expenditure in 1990 was spent on basic education activities and this had increased to nearly one half by 1994.

Surprisingly, the Bank's leadership role in the education sector is less evident among the three big Regional Development Banks (Inter-American, African and Asian). According to the DAC's Creditor Reporting System, collectively, these organisations committed 17 percent of their total education lending to primary education projects in 1983-84. By 1992-93, this had actually fallen to 3.4 percent. Secondary education, on the other hand, increased from 9.9 percent to 22.0 percent during the same period. The shares of higher education and vocational education and training did however fall very significantly, from nearly half to well under 20 percent which is consistent with World Bank policy recommendations concerning support for these types of education investments. Similarly, the share of 'education/training' doubled from 19.9 percent in 1982/83 to 40.4 percent in 192/93 which is indicative of the growing importance of sector-wide, policy-based lending.

The share of primary education in the total education budget of the EC fell from 6.0 percent during Lome III (1985-1989) to 5.0 percent during Lome IV (1990-1994).

\section{(c) The Bilateral Donors}

Despite the prominence that was given to the EFA World Conference and subsequent Declaration, coupled with new or renewed policy commitments by many (although not all) bilateral aid donors to supporting basic education, surprisingly few data are available on trends in the resource commitments of bilateral donors to basic education since Jomtien. As part of the EFA Mid-Decade Review, the EFA Forum Secretariat based at UNESCO's headquarters in Paris undertook a survey of the performance of bilateral and multilateral agencies in basic education (see EFA Forum Secretariat, 1996). While the report notes that "only a few donor countries have declined to join the international consensus in support of basic education", the data collected on resource commitments since 1990 are too patchy to be able to reach any firm conclusions. Only in the case of Germany is any firm evidence presented in the EFA survey that indicates a decisive shift in favour of basic education ${ }^{10}$ 
Table 7: Shares of expenditure on main education sub-categories by bilateral donors, 1983/84 - 1992/93

\begin{tabular}{lrrrrrr}
\hline & \multicolumn{3}{c}{ All Countries } & \multicolumn{3}{c}{ Sub-Saharan Africa } \\
\cline { 2 - 7 } Education Sub-Category & $1983-84$ & $1992-93$ & Change & $1983-84$ & $1992-93$ & Change \\
\hline & & & & & & \\
Education & 3.1 & 4.7 & 1.6 & 6.8 & 16.8 & 10.0 \\
Education/training & 25.5 & 17.4 & -8.1 & 13.8 & 28.8 & 15.0 \\
University & 11.1 & 21.7 & 10.6 & 9.2 & 10.8 & 1.6 \\
Higher technical institutes & 5.5 & 15.5 & 10.1 & 9.7 & 5.5 & -4.2 \\
Vocational training & 19.7 & 10.4 & -9.3 & 24.2 & 9.4 & -14.8 \\
Secondary education & 1.2 & 1.8 & 0.6 & 2.1 & 1.1 & -1.0 \\
Teacher training & 6.4 & 1.8 & -4.6 & 6.9 & 1.8 & -5.1 \\
Primary education & 9.7 & 9.3 & -0.4 & 6.4 & 13.6 & 7.2 \\
Non-formal education & 2.5 & 1.8 & -0.7 & 5.9 & 2.6 & -3.3 \\
Educational equipment/buildings & 9.7 & 11.7 & 2.0 & 7.2 & 4.4 & -2.8 \\
Other (residual) & 5.6 & 3.9 & -1.7 & 7.8 & 5.2 & -2.6 \\
Total & $\mathbf{1 0 0 . 0}$ & $\mathbf{1 0 0 . 0}$ & - & $\mathbf{1 0 0 . 0}$ & $\mathbf{1 0 0 . 0}$
\end{tabular}

Source: OECD/DAC Creditor Reporting System 
Fully recognising the limitations of the DAC's Creditor Reporting System data base, Table 7 presents the breakdown of bilateral donor commitments for all countries and Sub-Saharan Africa by main education category for the two periods $1983-84$ and $1992-93 .{ }^{11}$ It can be observed that:

(i) The share of total education aid explicitly targeted for primary schooling was in fact slightly lower in 1992-93 among the bilateral donors than in 1982-83 (9.7 percent and 9.3 percent respectively) but, that in Sub-Saharan Africa there was an appreciable increase - from 6.3 percent in 1982-83 to 13.6 percent in 1992-93.

(ii) The global share of higher technical institutes increased significantly, but fell in SSA. Interestingly, support for university education increased by over ten percentage points during this period, but remained largely unchanged in SSA.

(iii) The share of education aid targeted on secondary education remained tiny, both globally and in SSA;

(iv) The main losers were vocational training (down 9 and 15 percentage points for the total and SSA allocations respectively), and teacher training (down 4.6 percent overall and 5.2 percent in SSA).

But, given the serious problems of the CRS data, these trends in donor support for different education activities should be treated with extreme caution.

The data collected from our own survey of bilateral education aid during the 1990s along with reliable data from other sources are summarised in Tables 8 and 9. These show the percentages of total education expenditures allocated to primary and basic education (i.e. preschool, primary and adult education) by each bilateral donor country for the period 1989 to 1994/95. It is clear that for some donors (for example, SIDA in Sweden) ${ }^{12}$ a very considerable amount of additional support for basic education activities is subsumed in other education sub-categories (e.g. education planning, general budget support, teacher training), but since it is impossible to extract these expenditures, we have no option but to use the above narrow classification of basic education. It can also be observed that some countries only have figures for either basic or primary education (most notably France and Germany), but, between them, these two tables give a reasonably accurate picture of broad trends in the relative importance of basic education since Jomtien among the major bilateral donors.

At or around the time of Jomtien, only four bilateral donors (Denmark, Norway, Sweden, and the US) committed and/or disbursed more than 25 percent of their education sector expenditures on basic education activities. With the exception of Denmark, in the other three countries primary education received over 80 percent of this support for basic education. SIDA in Sweden was the first donor organisation to allocate a sizeable proportion of its educational budget to primary and non-formal education. From the mid-1980s, USAID in the US also began to reallocate resources in favour of basic education so that by 1990, it was by far the largest bilateral donor supporting basic education with disbursements approaching US\$ 250 million. 
Table 8 : $\quad$ Primary education expenditure as a percentage of total bilateral donor commitments to the education sector, 1989 - 1995

Country

1989

1990

1991

1992

1993

1994

1995

Bilaterals

$\begin{array}{lrrrrrrr}\text { Australia } & 8.4 & 9.5 & 7.0 & 9.9 & 7.8 & 5.5 & \\ \text { Austria } & . . & 0.0 & . . & . . & . . & . . & 0.6 \\ \text { Belgium } & . . & 5.9 & 6.1 & 5.3 & 3.6 & . . & . . \\ \text { Canada } & 0.0 & 0.6 & 0.2 & 2.0 & 0.6 & 12.6 & 9.9 \\ \text { Denmark } & . . & 17.0 & 10.1 & 15.2 & 17.2 & 15.1 & 20.2 \\ \text { Finland } & 0.0 & 3.8 & . . & 0.1 & 28.9 & 41.9 & . . \\ \text { France } & 4.4 & . . & . . & 17.0 & 20.0 & 20.0 & 14.0 \\ \text { Germany } & . . & 1.4 & . . & . . & . . & . . & . . \\ \text { Ireland } & . . & . . & . . & . . & . . & 8.1 & . . \\ \text { Italy } & 0.2 & 0.3 & 2.7 & 4.5 & 2.0 & 1.8 & 1.5 \\ \text { Japan } & 0.5 & 0.0 & . . & 3.8 & 0.0 & 16.1 & 6.7 \\ \text { Netherlands } & . . & 1.8 & . . & . . & 22.3 & 24.0 & 21.6 \\ \text { New Zealand } & . . & 2.5 & 5.0 & . . & . . & . . & 0.0 \\ \text { Norway } & 23.7 & 55.6 & . . & 48.9 & 37.3 & 6.9 & . . \\ \text { Portugal } & . . & . . & . . & . . & . . & . . & . . \\ \text { Spain } & . . & 0.0 & . . & . . & . . & . . & . . \\ \text { Sweden } & 56.0 & 75.0 & . . & 38.0 & 40.0 & 35.0 & . . \\ \text { Switzerland } & 1.1 & 4.4 & 3.9 & 1.9 & 8.0 & 12.0 & 15.3 \\ \text { USA } & 25.9 & 38.3 & . . & . . & 21.7 & . . & . . \\ \text { UK } & 4.8 & 4.5 & 13.9 & 10.9 & 10.4 & . . & 37.0\end{array}$

Multilaterals

EEC

6.0

5.0

UNICEF

$\begin{array}{lll} & & \\ . & . . & \\ . & . .\end{array}$

WFP

$\begin{array}{rrrr}. . & . . & 70.0 & 69.0 \\ . . & . . & 56.0 & . .\end{array}$


Table 9 : Basic education expenditure as a percentage of total bilateral donor commitments to the education sector, 1989 - 1995

Country

$1989 \quad 1990$

1991

1992

1993

1994

1995

\section{Bilaterals}

Australia

Austria

Belgium

Canada

Denmark

Finland

France

Germany

Ireland

Italy

Japan

Netherlands

New Zealand

Norway

Portugal

Spain

Sweden

Switzerland

USA

UK

Multilaterals

EEC

6.0

10.5

..

7.1

13.6

11.1

7.9

..

$\begin{array}{ll}. . & 15.6\end{array}$

..

12.5

.$\cdot$
.$\cdot$

8.4

..

12.9

5.7

.. 7.9

14.5

9.9

25.0

19.1

$\begin{array}{lll}. . & . . & 67.4\end{array}$

59.5

55.6

54.6

52.5

$15.6 \quad 8.0$

28.6

43.7

$4.4 \quad 0$

0.2

$3.0 \quad 2.3$

6.5

24.0

38.0

$1.5 \quad 0.0$

0.0

1.0

1.2

$\begin{array}{ll}0.5 & 0.0\end{array}$

3.8

0.2

16.1

10.7

9.2

35.5

39.8

23.6

AFDB

ADB

UNESCO

$23.7 \quad 55.9$

5.4

..

62.4

37.3

26.6

.. $\quad$..

$\begin{array}{ll}. . & 0.0\end{array}$

$66.0 \quad 81.0$

1.0

$4.8 \quad 12.9$

..

45.0

21.0

$31.0 \quad 53.2$

13.0

8.0

47.0

43.0

$\begin{array}{ll}5.9 & 1.7\end{array}$

18.3

14.

7.1

29.3

33.6

35.4

.. $\quad 33.6$

44.2

UNICEF

UNDP

WFP

$\begin{array}{rrrrrr} & 6.7 & & & & \\ . . & 34.8 & . . & . . & 26.0 & 47.0 \\ . . & 100.0 & . . & . . & 100.0 & 100.0 \\ . . & . . & . . & . . & 32.0 & . . \\ & . . & . . & . . & 91.0 & . .\end{array}$


In looking at trends in bilateral donor support for basic and primary education since 1990, the following four types of response can be identified:

(a) Significant increases in the commitment to basic education, with at least a 20 percentage point increase in funding share within the education sector. This group comprises four countries- Germany, Finland, Netherlands, and the United Kingdom. ${ }^{13}$ The increase in German support for basic education has been the most impressive - from 2.3 percent in 1990 to 38.0 percent in 1994. In absolute terms, this represents a net increase of US\$388 million, which is more than the net increase for all the remaining bilateral donors put together. The response of the ODA in the UK, while much less impressive in absolute terms, has nonetheless been equally dramatic in relative terms, with the share of basic education increasing from barely two percent in 1990 to over 40 percent by 1995 . The DGIS in the Netherlands was one of the first donors to review their education aid policies after Jomtien. A comprehensive and detailed strategy was published in 1992 which has been consistently implemented since then.

(b) Moderate increases, where the share of basic/primary education has increased between ten and twenty percentage points. Canada, Japan Switzerland, and, probably, France ${ }^{14}$ are the three key donors in this group.

(c) Minor increases, where the share of basic/primary education has increased by less then ten percentage points. This group includes Austria and Italy.

(d) Declines in the share of basic/primary education since 1990. While the share of basic education in Australia's education aid increased marginally between 1990 and 1995, the share allocated to primary education fell. In Belgium, the shares of both basic and primary education declined during this period. Three of the four donors (Norway, Sweden, and the United States) that prior to 1990 had the best records in support of basic education also recorded declines in the share of basic education. In the case of Sweden, this has in part been due to disbursement problems in two of SIDA's concentration countries. In the case of USAID, major cuts in the overall aid budget have made it impossible to maintain both the share and absolute size of disbursements to basic education. Disbursements fell from US\$225 million in 1991 to US\$ 125 million in 1994/95.

In overall terms, funding for basic education increased from around US\$350 million or 6.0 percent of total bilateral education aid in $1989 / 90$ to US\$1 billion or approximately 19.0 percent in 1994/95. In other words, in both relative and absolute terms, support for basic education has increased about three fold since Jomtien. However, Table 10 shows just how uneven the response has been among the bilateral donor community. Germany accounts for nearly two-thirds of the net increase of US\$ 630 million. Including the two countries with the next largest increases in basic education funding (Japan and the United Kingdom) brings this percentage to over 90 percent. Falling shares of basic/primary education and/or funding of education activities as a whole meant that some countries (Australia, Belgium, Italy, Norway, Switzerland, and the United States) spent less on basic and/or primary education in 1994/95 than in 1989/90. And, in another group of countries (Austria, Denmark, and Finland) net absolute increases are less than US\$ 10.0 million. Thus, we can conclude that among the 
large majority of bilateral donors the actual response to 'the challenge of Jomtien' has been either negative or fairly minimal.

What then are the main reasons for this disappointing response? In terms of formal policy, it is certainly the case that virtually all bilateral donors are now committed to supporting basic education. It should be pointed out however that while some donors (most notably the Dutch, Germans and the British) undertook comprehensive reviews of their education aid programmes soon after Jomtien (see BMZ, 1992: DGIS 1992; ODA, 1990), for others (including Australia, Canada, France and Japan) these reviews were not completed until 1994 or later. Consequently, at one level, the poor response to date can be simply attributed to bureaucratic and political inertia, so that with the majority of bilateral donors now formally committed to supporting basic education, it could be argued that the level of assistance for basic education is likely to improve appreciably during the next five years. However, there are a number of other factors that could militate against this outcome.

Table 10 : Change in annual resource commitments to primary and basic education between 1989-90 to 1994-95 (US\$ million)

Donor country Primary education Basic education

Australia

$-3 \quad 8$

Austria

1

Belgium

Canada

Denmark

Finland

France

40

Germany

369

388

Italy

Japan

140

Netherlands

Norway

Sweden

Switzerland

US

UK 
Stagnant or declining education sector budgets during the 1990s have undoubtedly been a major explanatory factor for this limited response among most bilateral donors. The case of Germany clearly demonstrates that where there is a clear policy commitment and significant additional resources can be allocated to the education sector as a whole, it is possible to increase very rapidly the level of a donor's support for basic education. But where overall resource availability decreases, effecting real changes in the pattern of resource allocations between different education activities becomes much harder. In the Netherlands, for example, the DGIS formally decided in 1992 to increase expenditure on basic education in SSA and South Asia by FL 100 million "over the next few years". However, because of cuts in the Dutch aid budget, this objective is only likely to be achieved by 1998 at the earliest. "Because funds available for country and regional programs have been falling and because the large proportion are required for on-going commitments, less money is available for new policy areas such as basic education" (DGIS, 1994:1).

There is also a group of bilateral donors who are still not convinced that they should make any significant changes to their policies and priorities with respect to education activities. In the main, this reflects genuine concerns about either their perceived comparative advantage in supporting primary and other basic education and/or the overall responsibility of national governments to fund these activities, and in particular formal primary schooling. AUSAID in Australia is fairly typical example of these concerns. While fully recognising that "there is now a clear trend towards the assistance for basic education among donors,... in considering aid programs in the education sector, it must be recognised that the provision of basic education is the primary responsibility of the recipient government" (AUSAID, 1995:22), and that, for this reason, aid to basic education must be carefully targeted. Similarly, the JICA Study Group on Development Assistance for Development and Education noted that Japan had found it difficult to support basic education in the past because "it was thought that basic education is not well suited to aid programmes because basic education involves people's morals, values, and customs, and accordingly aid in this area touches on a nation's culture and sovereignty, and because basic education targets huge populations, spread out over vast geographical areas" (JICA, 1994:39-49 quoted in King, 1995).

As noted earlier, the type of donor assistance that is invariably needed in order to make sustainable improvements in the provision of basic education is often different compared to the traditional areas of donor support for higher education and vocational training. Specifically, "process-oriented" changes that focus on the planning, financing, and management of education systems as well as curricula content and pedagogical practices are key components of most donor interventions with respect to primary education in contrast to earlier patterns of donor support for education where the main emphasis was on equipment and other hardware, overseas training of personnel, and foreign technical assistance for specific, isolated projects planned and implemented in a top-down manner. It is clear that many donors are finding it difficult to make this switch and follow "the fashion of moving from infrastructure to software" (King, 1995:10). This is especially so for donors like JICA in Japan where the bulk of assistance in the past has been for mainly large scale physical infrastructure projects. 
Recurrent expenditure is another key issue. Given the funding crisis that afflicts the education sector in most low income countries, donors who are serious about policy-based reform of basic education have little alternative but to accept that a sizeable proportion of incremental and, in some countries, recurrent costs will have to be met from their own resources. While there is now much wider acceptance of the need for this support and, either de jure or de facto, many donors do meet some of the recurrent cost burdens of the education activities that they assist, there are clearly still major concerns among the donor community about the extent to which they are prepared and/or able to do this.

Some smaller donors may also feel that the political sensitivities, technical complexities and sheer size of the interventions needed to achieve sizeable, sustainable improvements in primary and basic education even in small developing countries are such that this should be the preserve of the bigger donors (and the World Bank), and that they should therefore continue to support much the same types of educational activity as before. And, even where smaller donors are strongly committed to supporting basic education, in view of the critical minimum effort needed, they have little alternative but to target support for basic education in a few countries. However, in view of the wider political and economic objectives of bilateral aid programmes, there are political costs entailed in such strategy. Closer donor coordination would help to overcome some of these economies of scale in donor support for basic education, but there have been no significant improvements in donor coordination in the education sector in most developing countries since Jomtien.

This new approach also requires an altogether different type of involvement by recipient governments themselves. Given that the overall objective is to improve basic education provision for all or large parts of a country, governments must be highly committed to achieving education for all and, in particular, have to be prepared to shoulder the increase in recurrent expenditures that is usually needed to complement donor interventions. Thus, unless governments are prepared to make this commitment with all the attendant political risks and budgetary consequences, donor efforts to support basic education will be severely restricted.

More generally, this raises another key question namely, to what extent has the limited response of the bilateral donor community to Jomtien been the result of shortcomings in the capacities of recipient governments to take on the increased responsibilities, both managerial and financial, that increased donor commitment to basic education necessarily entails? This is particularly the case in SSA and other low income countries where concerns about the overall availability and quality of basic education are greatest. In its 1992-93 Progress Report on implementing its basic education objectives, the DGIS in the Netherlands neatly summarises the problems confronting donors in implementing the EFA objectives, particularly in SSA. The report concludes that "the SSA countries are lagging behind as far as the achievement of EFA objectives are concerned. This is the result of the difficult economic situation in these countries and the shortcomings of their governments' institutional capacity (good governance)..It is more difficult to achieve the cooperation with national and local authorities (e.g. in the form of financial contributions to education budgets which are regarded as essential) and where governments are unable to formulate the education plans required. The poor economic situation in the region as well as structural adjustment programs have had a negative effect. This means that it will take some time before the new Dutch policy on 
development cooperation and education can really have an effect, particularly in SSA" (DGIS, 1994:32).

Table 11: $\quad$ Expenditure on primary education as a percentage of total public education expenditure 1985/86 - 1992/93

\begin{tabular}{|c|c|}
\hline Country & $1985 / 86$ \\
\hline
\end{tabular}

\section{Africa}

Burundi

Ethiopia

Guinea

Kenya

Lesotho

Malawi

Niger

Swaziland

Togo

Zimbabwe

45.0

51.8

30.8

59.8

39.1

41.3

37.3

34.0

28.3

Asia

Bangladesh

China

India

Iran

Nepal

Syria

\section{Latin America \&}

the Caribbean

Costa Rica

Guatemala

Jamaica

Mexico

Nicaragua

Panama

Chile

Colombia

Ecuador

Paraguay

Suriname

Uruguay
46.1

28.6

37.1

40.9

35.7

38.4

35.1

-

29.9

27.4

43.3

38.3

51.0

39.2

45.5

36.6

63.7

37.7
46.8

53.9

32.8

58.1

51.0

48.1

25.8

32.9

30.4

30.5

45.6

31.5

38.1

33.2

48.2

38.5

34.5

29.5

34.7

26.7

38.5

37.0

49.2

32.1

31.3

43.9

60.5

37.5
44.5

53.6

35.0

62.3

48.8

55.4

30.1 (1991)

31.5

31.8

29.8

44.2

34.0

38.5

31.8

44.5

40.5

36.3

50.4

32.7

30.8

56.7

31.5

48.6

43.6

32.1

48.9

60.5

35.7

Source: UNESCO Yearbook of Statistics 
As usual, lack of data makes it difficult to assess the extent to which governments have increased their efforts with regard to basic education provision since Jomtien. Table 11 shows that among the ten SSA countries where at least some limited data are available, the share of primary education in total public expenditure on education increased by more than two percentage points during the three-four year period 1990-1992/93 only in four countries Guinea, Kenya, Malawi, and Niger), and actually fell in four others (Burundi, Lesotho, Swaziland, and Zimbabwe). In Asia, apart from China, the budgetary shares of primary education have remained largely unchanged or fallen, whereas in Latin America and the Caribbean, where primary enrolment ratios and literacy rates are much higher, the share of primary education expenditure has increased in two-thirds of the countries listed. Thus, while the World Bank is calling for "greater attention" to education, it is far from clear that client governments themselves are attaching top priority to education. In this regard, it is significant that under the European Community's Lome IV aid agreement, only 20 percent of the 70 ACP countries ranked education and training assistance as a high priority. In 45 countries it was a low priority and six countries there are no education and training projects at all (see EEC, 1995). While this may in part be a reflection of the assessment by ACP governments of the relative comparative advantage of the $\mathrm{EC}$ in the education sector, as was discussed earlier in connection with the dwindling levels of World Bank education lending in SSA, it is also the consequence of rapidly growing competition from other priority sectors and activities (especially the need to improve the efficiency and overall productive capacities of both the public and private sectors).

\section{CONCLUSION: HAS JOMTIEN MADE ANY DIFFERENCE?}

Given all the usual problems of counterfactuality and attribution, it is impossible to determine in a methodologically rigorous manner the exact impact that the Jomtien Conference and the subsequent EFA discussions and deliberations have had on levels of donor assistance for basic education. What is beyond doubt is that, with respect to formal policy discourses within the donor community as a whole, basic education now has a much higher profile than during the 1980s. However, the findings presented in this paper show that by the mid-1990s the translation of these policy objectives concerning basic education into funded projects and programmes in developing countries remained fairly limited among the large majority of bilateral donors.

By 1994/95, a small group of donors were spending an extra one billion US dollars a year on basic education, and Jomtien can certainly take some of the credit for helping to generate these additional resources. But this level of funding is still seriously inadequate if the EFA targets for 2000 are to be met. It will be recalled that in the early 1990s Haddad and Colclough and Lewin estimated that donors would have to make available an additional US\$10-25 billion for basic education over a ten year period in order for the Jomtien EFA objectives to be fulfilled by 2000. Roughly speaking, by 1995 no more than US\$3-4 billion had been forthcoming from both bilateral and multilateral donors. This means that annual average contributions will have to be at least US\$2 billion during the remainder of the decade just to meet the more conservative Haddad target. Given the current funding crises facing most donors, this seems highly unlikely. 
What is also worrying is that by 1995, progress in meeting the EFA targets was fairly limited. The number of out-of-school children of school age had fallen by only 19 million - from 129 million in 1990 to 110 million in 1995. And in SSA, the number of children without access to primary education actually grew by two million (see UNESCO, 1996). Unfortunately, data on the regional breakdown of bilateral expenditures on basic education are incomplete. But a reasonable assumption is that SSA has accounted for approximately half of total basic education expenditures in which case an extra US\$ 300 million was being spent by the bilateral donors in SSA in the mid 1990s. Including the extra US\$25-50 million of World Bank lending plus another US\$ 50 million from the other multilaterals increases this figure to at most US $\$ 400$ million a year. There are at least 40 million out-of-school children in the continent as a whole, little or no progress is being made in improving the very low quality of learning outcomes in primary schools in most countries, and rates of adult illiteracy remain very high. It is clear therefore that far greater resources will need to be forthcoming from both the bilateral and multilateral donors if the EFA objectives are to be met in SSA by 2010 let alone 2000.

The Working Document prepared by the EFA Secretariat at UNESCO for the Mid-Decade Meeting of the International Consultative Forum on Education for All concludes that "the concept of Education For All has definitely gained wider currency world-wide and inspired numerous resolutions and policy statements, as well as legislation and educational planning. However, not all countries have matched the rhetoric with determined action, and many of those that are committed to EFA face difficult problems ahead...Multilateral and bilateral funding agencies are contributing to basic education in many countries, but this assistance is often marginal and certainly not adequate to meet the challenges of EFA" (UNESCO, 11996:43-45). In short, there has been a "Jomtien effect" but there is "no room for complacency".

While this conclusion is largely correct, what is missing is both an assessment of the short to medium term prospects for donor funding of basic education and a more detailed strategic vision of the role of the donor community in meeting the EFA objectives with some idea of the likely overall resource requirements. There are clearly some grounds for optimism. In particular, basic education is now firmly established as a central objective of education aid by virtually all donors, bilateral and multilateral. But, on balance, we are inclined to be more pessimistic. On the supply side, total aid flows will continue to decline and competition for the available resources among a widening array of end-uses will inevitably intensify while, on the demand side, the problems already being encountered in effectively disbursing donor resources for basic education especially in SSA will remain as difficult as ever. And like all development fashions, there is always a danger that the attentions of the donor community will be diverted to other new priority areas in the future. Sustaining the vision of Jomtien will remain therefore as great a challenge as ever. 


\section{REFERENCES}

AUSAID, Australian Agency for International Development (1996) Education and Training in Australia's Aid Program: Policy Statement (Canberra: AUSAID).

AUSAID (1995) New Directions in Australia's Overseas Aid Program (Canberra: AUSAID).

Buchert, L. (1995) Recent Trends in Education Aid: Towards a Classification of Policies. A Report for the International Working Group on Education. International Institute for Educational Planning (Paris: UNESCO).

Buchert, L. (1994) "Education and Development: A Study of Donor Agency Policies on Education in Sweden, Holland and Denmark", International Journal of International Development, Vol. 14, No. 2, April.

BMZ, Bundesministerium fur wirtschaftliche Zusammenarbeit and Entwicklung, (1996) Basic Education in German Development Cooperation (Frankfurt: KfW/GTZ).

Promotion of Basic Education in Developing Countries: Sector Concept (Bonn: $\mathrm{BMZ}$ ).

CIDA, Canadian International Development Agency, (1996) Africa and Middle-East Branch. Bilateral Expenditures on Education and Training. Fiscal Years 1985/86-1995/96 (Ottawa: CIDA).

Colclough, C. with K. Lewin (1993) Educating all the children: strategies for primary schooling in the South, (Oxford: Clarendon Press).

Destafano, J., A. Hartwell, A. and K. Tietjen, (1995) Basic Education in Africa (Washington, D.C: USAID).

EFA Forum Secretariat, EFA Mid-Term Review: Performance of Bilateral and Multilateral Agencies in Basic Education (Paris: UNESCO).

EEC, European Commission, (1995) Analysis of the European Union Member States Policies and Activities in the Field of Education and Training to Developing Countries (Brussels: European Commission).

Frederiksen, B. (1990) Increasing Foreign Aid for Primary Education: The Challenge for Donors. Education and Employment Division, Population; and Health Research Department. (Washington, D.C: World Bank).

Haddad, W.D. (1990) "Education For All: the Role of International Aid," Prospects, Vol. 20, No. 4.

King, K. (1995) "Aid For Development of for Change? A Discussion of education and Training Policies of Development Assistance Agencies with particular reference to Japan" (Edinburgh: mimeo). 
King, K. and R. Carr-Hill, (1992) International Aid to Basic Education: Flows, Policies, Modalities. Occasional Papers No. 38, Centre of African Studies (Edinburgh: Edinburgh University).

Lewin, K. M.(1994) British Bi-Lateral Assistance to Education: How Much, To Whom and Why? International Journal of Educational Development, Vol. 14, No. 2, April.

Lockheed, M. and A. Verspoor (1990) Primary Education in Developing Countries (Washington, D.C: World Bank).

ODA, Overseas Development Administration (1995) Progress Report on ODA's Policy Objectives (1992/93 to 1993/94) (London: ODA).

Netherlands, Ministry of Foreign Affairs, Directorate-General for International Cooperation (DGIS), (1992) Development Cooperation and Education in the 1990s (The Hague: Government Printer).

, 1994, Basic Education 92-93. Sectoral and Thematic Progress Report (The Hague: Government Printer).

New Zealand, Ministry of Foreign Affairs and Trade, (1993) Evaluation of NZODA to Education and Training in Asia, Africa, and the Americas: An Overview (Wellington: Ministry of Foreign Affairs).

(1993) Evaluation of NZODA to Education and Training in the South Pacific (Wellington: Ministry of Foreign Affairs).

Sweden, Swedish International Development Authority, (1996) An Overview of SIDA Education Programmes 1992/93, 1993/94, 1994/95 (Stockholm: SIDA)

UNESCO, (1996) Education For All: Achieving the Goal. Working and Statistical Documents for the Mid-Decade Meeting of the Consultative Forum on Education For All (Amman: UNESCO).

UNESCO/UNICEF/UNDP/World Bank, (1990) World Declaration on Education For All (Paris: UNESCO).

Wood, Adrian, (1994), North-South Trade Employment and Inequality: Changing Fortunes in a Skill-Driven World, (Oxford: Clarendon Press).

World Bank, Annual Reports, 1986-1996 (Washington, D.C: World Bank).

World Bank, (1995), Priorities and Strategies for Education: A World Bank Review (Washington, D.C: World Bank). 


\section{END NOTES}

1. In the World Bank's 1995 Education Sector Review the definition of basic education was extended to include lower secondary education.

2. The only major donor that did not provide data was the United States. The other nonparticipating smaller donors were Belgium, Denmark, Finland, and Norway.

3. It should be pointed out however that in 1990, the year when the Jomtien Conference was held, the share of total Bank lending to the education sector was 7.2 percent, considerably lower than the corresponding figure of 10.2 percent for the bilateral donors as a whole. Only in 1994 did the share of education in total Bank (IBRD and IDA) lending reach the same level as for the bilateral donors.

4. The Jomtien Conference was co-sponsored by three UN agencies (UNESCO, UNICEF, and UNDP) and the World Bank.

5. Cumulative World Bank lending for education comprised 9.0 percent of total lending between 1990 and 1996. The corresponding figures for IBRD and IDA loans are 7.3 and 12.5 percent respectively.

6. There is a very large divergence between the imputed value of education commitments by France based on DAC data and the actual expenditures reported by the French Ministry of Cooperation. Typically, DAC estimates are 4-5 times greater.

7. This figure for SSA is slightly distorted by two very large loans to Cote d'Ivoire for "human resource development" in 1992 and 1994.

8. The Latin America and Caribbean region is an important exception to this rule however. Brazil in particular borrowed over US\$ million between 1991 and 1996 for primary and other basic education projects.

9. According to figures obtained by Lene Buchert (1995), UNDP devoted 32 percent of its education expenditure to basic education in 1994.

10. A one year increase in support for basic education from the Netherlands is reported- from US\$11.4 million in 1992 to US\$ 18.6 million in 1993 as well as an increase by Finland of its allocation to basic education from 28.6 percent in 1993 to 43.7 percent in 1994.

11. At the time of writing (late 1996), some donors (most notably USAID and SIDA) had still not submitted all project data for 1994 so unfortunately it is not possible to include this year in the analysis.

12. If SIDA's expenditures on "activities which support the implementation of basic education programmes" (SIDA, 1996:5) are included as well as for "special (education) programmes" (most notably education NGOs in South Africa), the share of basic education in total education expenditure increases to well over 75 percent.

13. Denmark may also belong to this group (see Table 1) but the available data are not good enough to be entirely confident about this. 
14. The data for the proportion of French aid allocated to primary education have been supplied by the Ministry of Cooperation for the years 1992-1995. However, the base year 1989 is from the CRS and is likely therefore to be much less reliable.

15. For three countries, Canada, France and Netherlands, the DAC data indicate that their education aid expenditures were exceptionally high during 1989 and 1990. The reasons for these increases are not known, but what is clear is that education aid from all three countries declined significantly during the 1990s. 